\title{
Hawthorne's Attitudes Toward His Ancestors' Religious Belief As.Reflected In "Young Goodman Brown"
}

\author{
: $;$ \\ Niken Anggraeni \\ State University of Yogyakarta
}

\begin{abstract}
This paper discusses Hawthorne's attitudes toward his ancestor's religious belief depicted in his work "Young Goodman Brown". The analysis is conducted by using sociological approach as this approach concentrates on the social context of writing or on the literary text and its social meaning. It also explores the relationship between the artist and society as this approach believes that the writers are part of the world they describe. Thus, the biographical sketch of the author is also presented to support the analysis.

Based on the analysis, it can be concluded that "Young Goodman Brown" reveals Hawthome's skepticism toward Puritanism, his ancestors' religious belief. The main character's inner conflict dealing with his religious belief portrays the writer's question on the worth of the very strict doctrine that his ancestors possessed. Expressing his anti-Puritan view, he creates the setting of the story which reminds his audience of the outrageous trials conducted by Puritans in 1692 known as Salem Witch Trials. He also borrows the characters' names from the victims of those trials. The downfall of his tragic hero caused by his distrustful feeling toward his own religion also indicates Hawthorne's skepticism to Puritanism.
\end{abstract}

Keywords: sociological approach, skepticism, Puritanism.

\section{A. Introduction}

Literary works cannot be separated from the society since literary works often depict the phenomena which happen in it. This is in line with Burns's statement mentioning that "a literary work should be considered as a social phenomenon" (Bums 35). Furthermore, it is believed that what the writers create is 
influenced by the society in which they live. Therefore, sociological approach is often used to analyze literary works. This approach is intended to relate the experiences of the characters to the historical climate from which they derive (Taine in Swingewood, 1972: 14). In view of that, a research using this approach should concentrate on the social context of writing or on the literary text and its social meaning. However, according to Swingewood (1972), the writers not only articulate social values within their work, but they are part of the world they describe. In this case, sociological criticism also explores the relationship between the artist and society.

In American history of literature, Nathaniel Hawthorne is famous as a romantic, and well known for his allegorical tales. One of his great tales is "Young Goodman Brown", which reveals a man's inner conflict related to his religious belief, i.e. Puritanism. Hawthorne himself was born in a family with Puritan tradition in England and although he was never a Puritan, he could not escape the influence of Puritan society (---- 1975). As the words used by the author can convey his or her attitudes toward the subjects s/he talks about, Hawthorne's attitudes toward this religious belief may be revealed through his work "Young Goodman Brown", which talks about people holding Puritanism. Since sociologists of literature believe that authors cannot be separated from their works, it is necessary to analyze this work by using sociological perspective.

According to High (2000) most of Hawthorne's literary writing reflects his ambivalence toward his Puritan ancestors' religious belief. He names Puritans as hypocrites in many of his works. Due to what has been mentioned previously, it is said that through his books he views his Puritan ancestors with a skeptical, dualoutlook on life. He is proud of the history of his family regarding their prominence and accomplishments, while at the same time he also feels guilt for his ancestor's part in witch trials and the evil prosecution (High 49).

\section{B.Biographical Sketch Of The Author}

Hawthome was boin in 1804 in Salem, Massachusetts, an area which was still influenced strongly by Puritanism. He was the son of a puritan and a grandson of a judge at the notorious Salem witchcraft trials. Bom in a family with Puritan tradition in England and although he himself was not a Puritan, Hawthorne could not escape the influence of Puritan society (---- 1975). He lived a reclusive life 
starting at four when his father died of yellow fever. His mother, Elizabeth Clark Manning Hawthome, and her three children were forced to move back to her father's house.

In a house filled with thirteen others and a mother who mourned her husband in seclusion, Nathaniel found it necessary to spend as much time alone as possible. Therefore, the solitary characters found in Hawthorne's short stories were based on his own life. His interest in reading began at seven when he injured his foot in a ball game and recuperating for several years introduced him to literature (Hart 320).

In brief, based on the explanation above, it can be seen clearly that Hawthome was quite familiar with the life of puritans and even belonged to a puritan family. Consequently, many of his works were influenced by this fact.

\section{Discussion}

\section{Brown's Inner Conflict dealing with his Religious Belief}

In the story "Young Goodman Brown", Hawthome endeavors to reveal an inner conflict dealing with a man's faith in religion and awareness that a dutiful person can have a kind of intimate relation with the devil. This can be observed from the main character's problems depicted in the story, which show how a good man is tempted to join the devils worshippers in a dark forest, and how this temptation finally leads him to his down fall as he reveals that the people in his village are part of that deviate community, and, therefore, they are regarded as sinful people.

The story starts with a man named Goodman Brown, who wants to have a joumey into the dark forest at sunset. He leaves his beautiful wife, Faith, to whom he married three months before. Although his young wife begs him to delay the trip until sunrise as she says that "a lone woman is troubled with such dreams and such thoughts" (Gioa 348), he insists. Turning down the request of his wife, he thinks that the deed in the dark forest, whatever it is, should be conducted soon.

Furthermore, Goodman Brown is told as a dutiful Puritan man and part of the community of "honest men and good Christians" (349). He claims himself as "a people of prayer and good works, and abide no such wickedness" (350). This 
indicates how Brown regards himself and his ancestors as good Puritans, and, thus, it hints that he is only an ordinary man holding an ordinary belief at that time, i.e. Puritanism.

Despite his being religious, this good Puritan gentleman, then, for his own reason whatsoever, makes a deal with the Devil in the dark forest outside Salem. This can be inferred from his conversation with his companion. This man, however, realizes that this deal is morally wrong regarding his own remarks on himself and his ancestors. Besides, on his way to the dark forest he keeps remembering his previously good conducts. He also feels uncomfortable to know that, there, in the forest he will meet some of the very respectful people, such as the governor and the minister, on the weekday when everyone must go to church to hear a sermon or Bible-reading, which is also the Sabbath. This considerably puts him in doubt whether he should continue his trip or not.

"Can this be so!" cried Goodman Brown, with a stare of amazement at his undisturbed companion. "Howbeit, I have nothing to do with the governor and council; they have their own ways, and are no rule for a simple husband like me. But, were I to go on with thee, how should I meet the eye of that good old man, our minister, at a Salem village? Oh, his voice would make me tremble, both Sabbath-day and lecture-day!" (Gioa, 2002:350).

This shows how in this part Brown undergoes an inner conflict. This conflict is resulted from his moral belief, for what he is doing is actually in contradiction with his faith. To convince Brown and to keep him still in this path, his companion deceives him by saying that he is supposed to continue his will and that his uncomfortable feeling is ridiculous. When Brown mentions Faith as one of the reasons for him to quit his journey, his companion gives his word and assures Brown that there will be no harm upon her which can be resulted from the journey.

The inner conflict possessed by Brown continues when on his way he sees many more religious people in his village, including the one who taught catechism in his youth and is still his spiritual advisor, are also making their ways to the forest.

"Of this fact, however, Goodman Brown could not take cognizance. He had cast up his eyes in astonishment, and looking down again, beheld neither Goody Cloyse nor the serpentine staff, but his fellow traveler alone, who waited for him as calmly as if nothing had happened "That old woman taught me my catechism!" said the young man; and there was a world of meaning in this simple comment (Gioa, 2002:351) 
Being upset by this fact, Brown suffers from a stronger inner conflict. He makes up his mind and says to his companion that he will not continue his journey.

"Friend," said he, stubbomly, "my mind is made up. Not another step will

I budge on this errand. What if a wretched old woman do choose to go to the devil, when I thought she was going to Heaven! Is that any reason why I should quit my dear Faith and go after her?'(Gioa, 2002:352).

In spite of his heavy sickness of his heart he is still strengthened by his faith in the existence of heaven and in his innocent wife.

"With Heaven above, and Faith below, I will yet stand firm against the devil!" cried Goodman Brown (Gioa, 2002: 353.

For this reason, when he finds out that his wife Faith also joins the diabolic meeting in the forest, he looses his all faith. He refuses to face the fact that the sinful natures are not only found in him but also found in his father, his grandfather, his church community, even his religious adviser that taught him his catechism, and most horrifyingly of all, his wife, the symbol of his faith. At this point, the spiritual crisis that Brown encounters begins.

The reason of Brown to have the journey, however, is not clearly stated in the story. Even so, some possible and logical reasons can be found. The first possible reason is his curicsity. He is really interested to see witches and their ritual ceremonies in the forest. As a good puritan he might never experience such rite, and, therefore, he is curious in witnessing what it is. On the other hand, he might also be actually tempted to join the devil-worship based on his personal reason whatsoever. This means he, in fact, owns an inner desire to be a witch, and afterward it can be assumed that he intentionally enters the forest to meet the witches and join their dark community.

Later on, when Brown returned to his village, he discovers that life goes on as usual. However, the most important thing aroused after his journey is that coming back to Salem from that dreadful night, he becomes an extremely different person. He is overburdened with the heavy sickness of his heart thinking about how those holy men could "be journeying, so deep into the heathen wilderness" (353). $\mathrm{He}$ forgets the fact that, actually, he is also sinful as he was the one who has an intension to join that witches ritual ceremony, too. He does not have any faith in his fellow townspeople anymore, for he considers them sinners. As he says "there is no good on earth: and sin is but a name" (353), he suddenly becomes a very distrustful 
man. Moreover, he turns into a very cold husband to his wife Faith, and he remains cynical and bitter until he dies.

"Often, awakening suddenly at midnight, he shrank from the bosom of Faith, and at morning or eventide, when the family knelt down at prayer, he scowled, and muttered to himself, and gazed sternly at his wife, and turned away" (357).

From the narration above, it can be noticed that his life is really disturbed by what he previously sees in the forest. Finding out the fact that the religious people in his village are actually part of a dark community, he looses his all faith.

At the end of the story, Hawthorne shows his reader that Brown's lack of faith ultimately destroys his life, and all of the beliefs that he has built his life upon are crushed. Whether good or evil wins the fight within Brown is not clearly stated, but Hawthorne makes it abundantly clear that his tragic character is eventually scarred for life by his experience in the dark forest.

Considering the incidents happened in the story, the central theme of Hawthorne's "Young Goodman Brown", therefore, is the inner conflict in Brown between joining the community who worship Devil and remaining "good". It can also be seen that the journey is a very difficult one for him because it never becomes an easy decision for him whether he should follow his inner desire to become a witch or he should not leave all the good things he has behind, including his religious faith and his wife, Faith. At the end, this internal conflict apparently destroys his spirit of life and turns him into a very different person.

All this has given evidence that Brown, the main character of the story, undergoes a kind of inner conflict dealing with his religious belief. This inner conflict appears because his strong belief of the strictness of his religious teaching is confronted with his will to go to the forest to join the diabolic meeting. Knowing the fact that not only he but also many religious people in his village, including his wife, want to join the devil worship in the forest, he turns to be a distrustful person. He looses his faith on the holiness of his moral belief and is doubtful whether there is any. Brown's way of thinking and attitude toward his religious believe may reflect Hawthorne's attitude toward Puritanism. 


\section{Hawthorne's Skepticism toward Puritanism as Reflected in Brown}

As what mentioned before, Hawthorne was bom in a family with Puritan tradition in England. Although he himself was not a Puritan, he could not escape the influence of Puritan society. His best work usually has a strong feeling for the Puritanism. However, most of his literary writing reflects his ambivalence toward his Puritan ancestors' religious belief. In many of his stories, he is proud of the history of his ancestors regarding their prominence and accomplishments, while at the same time he also feels guilt for his ancestor's part in witch trials and the evil prosecution to the Quaker. Moreover, he is also disappointed to see the cruel intolerance of his Puritan ancestors and to know that the Puritans' belief in witches was strong enough proof for Hawthorne's ancestors to sentence about twenty people in Salem to death based on purely ghostly evidence, which does not seem fair. He even names Puritans as hypocrites in many of his works proving how he views his Puritan ancestors with a skeptical, dual-outlook on life (Gioa 350).

Like what previously mentioned, during the $17^{\text {th }}$ Century people's belief in evil forces such as witches, warlocks, and diabolical spirits was widespread in America (Levin 83). In Salem, Massachusetts, in 1692, the courts accused more than a hundred people of witchcraft. The accused people were put in jails, and about twenty of them were sentenced to be hanged.

According to Hawthorne, what happened in Salem, Massachusetts, in 1692 was because of the distrust among the people which precipitate the chaotic situation in that place (High 18). Further he states that based on his closed study on his ancestors' religious belief, it seems that Puritanism taught that one could not trust anyone as in the witch trials men had the heart to turn on their accused wives (19).

In the story "Young Goodman Brown", Hawthorne uses some history of the Puritan faith to help the reader possess a better understanding of the story. He creates Brown's inner conflict caused by his religious faith, which reflects Hawthorne's attitude toward his ancestors' religious belief. Here, he uses allegories and other symbols throughout the text to help emphasis the story's theme. His use of these allegories and other symbols shows how his character changes from good into evil and struggles with his disappointment with his own belief until the day he dies. 
Through the use of mysterious symbolism, unique characters, and an intriguing plot, Hawthome builds the suspense of the reader until the shocking climax is revealed. His character, Brown deals with some secret guilt or problem which keeps him at a distance from other people. He is troubled by his personal feeling of distrust, as he believes that the evil is hiding in every human's heart. At the end of the story, it can be concluded that the isolation of the main character is caused by his distrust.

As an allegorical tale, this story employs some symbols. The name of Brown's wife is believed to be the symbol of his faith in his religion. The characters Goody Cloyse, the minister, and Deacon Gookin are also symbolically important because they are the people who he believes to possess complete faith and the inability to be swayed by the devil. The Puritans' belief that the forest at night was evil and that those who enter.must be also be evil is also the symbol which represents Puritans' strict belief.

Apparently, Hawthorne's "Young Goodman Brown" is the manifestation of his own feeling of guilt that he felt because of his ancestors' involvement in the Salem witches trials. Through his character, he shows his reader that his ancestors' strict religious belief is harmful. To give a clearer atmosphere of the Puritanism background in his story, Hawthorne borrows from history the names of two "Goodys"- Goody Cloyse and Goody Cory- and an unmarried woman, Martha Carrier, who were in 1692 condemned to be hanged by Hawthorne's great grandfather in Salem Witch Trials (Gioa 350).

In this work, Hawthorne does not reject the Church or God through the language he employs. However, it is clear that he tries to make his reader aware of the dangers of strict moral teaching. In this story, in fact, the religious people become hypocrites. They seem religious at noon but become the devil worshippers at night. Therefore, it can be seen clearly that in "Young Goodman Brown" Hawthome questions the worth of Puritanism through what happens with his tragic character. Moreover, he apparently tries to hint that a lack of faith and forgiveness can destroy one's life and what he believes in. To conclude, as he puts his own biographical framework in this story, it can be said that, in this story, what the main character thinks about his religious belief reflects Hawthome's skepticism on it.

From the discussion above, it can be inferred that Hawthorne, trying to question the merit of Puritanism through this work, depicts his main character's 
tragic life in such a symbolic way. He is successful in figuring out how that very strict belief possessed by his ancestors leads to the downfall of his tragic hero.

\section{Conclusion}

Considering what sociologists of literature believe that writers not only articulate social values within their works, but they are also part of the world they describe, it can be concluded that "Young Goodman Brown" reveals Hawthome's attitude toward his ancestors' religious belief. Observing the main character's inner conflict, it can be assumed that he tries to question the merit of Puritanism by depicting the downfall of his tragic hero.

Regarding his feeling of guilt to the victims of the evil trials, Hawthorne, by creating Brown's inner conflict dealing with his religious belief, portrays his question on the worth of the very strict doctrine that his ancestors possessed. He expresses his anti-Puritan view through the setting of his story which reminds his audience of the notorious trials conducted by Puritans in 1692 known as Salem witch trials. The revelation of his view is also seen from the characters' names mentioned by Hawthome, which he borrows from the victims of Salem Witch Trials. The extremely negative changes of the main character from a good Puritan to a very distrustful person, who then ends up in an unhappy life because of his religious belief, also indicates his skepticism to Puritanism.

\section{Bibliography}

Gioa, Dana. The Longman Masters of Short Fiction. New York: Longman, 2002.

Hart, James. The Oxford Companion to American Literature. Boston: Houghton, 1965.

High, B. Peter. An Outline of American Literature. New York: Longman, 2000 Grolier Academic Encyclopedia. $7^{\mathrm{t}}$ vol. Chicago: Field Enterprises Educational Corporation, 1991.

Levin, David. What happened in Salem? 2nd ed. New York: Harcourt, Brace and World Inc, 1967. 